Article

\title{
On "Genuine" and "Illegitimate" Refugees: New Boundaries Drawn by Discriminatory Legislation and Practice in the Field of Humanitarian Reception in Germany
}

\author{
Anne-Kathrin Will \\ Berlin Institute for Integration and Migration Research (BIM), Humboldt-University, 10099 Berlin, Germany; \\ E-Mail: ankawill@gmx.de
}

Submitted: 29 March 2018 | Accepted: 5 June 2018 | Published: 30 August 2018

\begin{abstract}
A high number of legal changes accompanied the increase of people seeking asylum in Germany throughout the 18th legislative period from 2013-2017. These changes have transformed the field of humanitarian reception in Germany, especially along the axes of citizenship, integration performance and deviation from administrative and legal rules. Half of the legal measures from this period have led to differential rights for different groups of asylum seekers according to one of these three axes. The axis of citizenship has also structured the development of administrative procedures referred to as "integrated refugee management" which was established to speed up asylum seeking processes, classifying persons applying for a humanitarian residence visa in Germany into four clusters. This categorization, too, led to different entitlements regarding the admittance to state-financed German courses and integration measures focussed on education and the labour market. In this article I employ the notion of differential inclusion (Mezzadra \& Neilson, 2012) to analyze these legal and administrative changes. I show that they have reshaped the substructures impacting the lives of those categorized as "genuine" and "illegitimate" refugees and thus redrawn the boundaries and created hierarchies among those seeking humanitarian protection in Germany.
\end{abstract}

\section{Keywords}

differential inclusion; Germany; humanitarian reception; integration; refugee management

\section{Issue}

This article is part of the issue "Migration, Boundaries and Differentiated Citizenship", edited by Terry Wotherspoon (University of Saskatchewan, Canada).

(C) 2018 by the author; licensee Cogitatio (Lisbon, Portugal). This article is licensed under a Creative Commons Attribution 4.0 International License (CC BY).

\section{Introduction}

People who migrate are often categorized according to the aim which led them to migrate or to the governments' reasons for granting or not granting residency rights. The German National Contact Point of the European Migration Network (EMN) differentiates between four kinds of migration in its annual reports: "legal mi- gration and mobility", "irregular migration", "return migration" and "international protection and asylum". This categorization implies that migration for humanitarian reasons is not considered a legal form of entry per se. Only if an individual's asylum procedure ${ }^{1}$ is successful can he or she have access to integration measures ${ }^{2}$ available to those categorized under "legal migration and mobility" (BAMF, 2017b, p. 7). This raises questions about

\footnotetext{
${ }^{1}$ During asylum procedures it is decided which kind of protection applicants are entitled to: 1) asylum as enshrined in the German constitution, 2) recognized as refugees under the Geneva Convention, 3) subsidiary protection, or 4) protection due to an (inter-)national ban on deportation (BAMF, 2016d, p. 35). In public use the term "refugee" is not exclusively used for these four groups as also evident in administrative terms such as "integrated refugee management", which concerns all new asylum seekers or "refugee integration measures".

2 Integration measures contain foremost the official German language and society course (Integrationskurs), further German language courses linked to the labour market, employment opportunities and measures which aim at vocational education and entrance into the labour market.
} 
who is seen as a "genuine" refugee: who is entitled to receive support or simply to reside in Germany and who may thus transfer into the category of "legal migration and mobility". The table of contents of the annual reports of the EMN mirrors the hierarchical logic of the migration regime and the potential upward movement of an accepted refugee's or asylum seeker's status inside this hierarchy. During asylum-seeking procedures, it is not clear into which category the applicants will fall in the end: if they will be accepted and potentially rise to the category "legal migration and mobility" or be denied and drop to the category "return migration". For this article all three groups (i.e., asylum seekers in midprocess, those accepted and those denied) are considered together as target group of the system of humanitarian reception in Germany.

This system is fragmented. In 2009 seventeen legal forms of humanitarian protection existed (Parusel, 2009, p. 43). Since then four additions have been made in the section regulating humanitarian and political residence rights ( $\$ 25$ was restructured, including a European and national ban on deportation, §25a and $\$ 25 b$ were new additions) and a fifth addition is included in $\$ 18 a$ (employment-based residence permits for qualified persons with an exceptional leave to remain) in the labourrelated regulations of the Residency Act. Thus, a total of 22 different types of humanitarian residence rights exist in Germany, accompanied by three additional status categories which are bound to registration and administration of foreign nationals without a right to residence (i.e., exceptional leave to remain/"toleration", preliminary entitlement to remain in the country and proof of arrival). To describe humanitarian reception in Germany, all these different kinds of rights and non-rights have to be considered together, since people's statuses change and these statuses are related to one another in a hierarchical way, as evident from their differential access to resources.

Mezzadra and Neilson employ the concept of "differential inclusion" to describe the stratified rights granted to migrants in immigration countries. They link this concept to labour migration and highlight its relation to capital (Mezzadra \& Neilson, 2012, p. 183). But differential inclusion is also relevant for the part of migration to Germany which I describe under the overarching term "humanitarian reception". By definition, international protection and asylum should not be tied to capital. But the new regulative policy in the field of humanitarian reception makes demands on applicants' performance with regard to what is called "integration", including gaining knowledge of the German language and contributing to the social welfare system by paying obligatory social security and pension insurance, and therefore not becoming dependent on social benefits. Since 2015, measures have been taken to support the labour market entry of people with a high probability of receiving a residence permit on humanitarian grounds. Labour experts characterize this policy move as a "lane change" (Spurwechsel), pointing to the formerly unthinkable connection be- tween labour market interests and humanitarian protection (Bojadzijev, Mezzadra, Altenried, Höfler, \& Wallis, 2016, p. 269).

To understand this "lane change" one has to consider that until 2005 different kinds of residence status were strictly divided. For example, international students had to leave Germany after graduation, even if they had found employment. But from 2005 on students gradually came to be viewed as "model migrants", resulting in several liberalization measures aiming to promote their stay in Germany after graduation (Morris-Lange \& Brands, 2015, p. 15f; Sykes \& Ni Chaoimh, 2012). Since the reissued Residency Act (Aufenthaltsgesetz) came into force in 2005 , these categories have increasingly become intertwined, blurring the divisions between them (Grote \& Vollmer, 2016). Even humanitarian residence statuses have become increasingly infused with performancebased conditions and rights, most intensively between 2014 and 2016. After the Integration Act was issued in 2016 performance-based conditions and rights even became relevant for persons found to be entitled to asylum and recognized refugees under the Geneva Convention. People in this group now have to wait two years longer for a permanent residence visa if they do not quickly and successfully "integrate". Until 2016 a permanent residence permit was issued after a minimum of 3 years, dependent upon whether or not the applicants' claims for humanitarian protection were still found to be relevant. This minimum waiting-time to get a residence permit was prolonged in 2016 to 5 years. It could only be reduced to the previous waiting-period of three years if the applicant showed a high level of integration performance at that point, having mastered the German language and attained financial independence.

In this article I argue that a series of legal changes during the 18th legislative period from 2014 until 2017 has restructured the field of humanitarian reception in Germany. I isolate three factors used to differentiate between different groups: applicants' citizenship, his/her performance and criminalized deviations. Criminalized deviations include strictly penalized conflicts with the German administration which most commonly arise when individuals "fail to cooperate" as required by the application or appeal procedures (Mitwirkungspflichtverletzung). Symptomatic for the factor citizenship is a new set of procedures called "integrated refugee management", employed in 2016 and abandoned in 2017. I discuss the three structural factors for humanitarian reception at the end of the main part of this article, using the concept of differential inclusion, and I will make my concluding remarks about the consequences for humanitarian reception in Germany.

\section{Legal Changes from 2014 to 2017: Restructuring of the Field of Humanitarian Reception in Germany}

Humanitarian reception in Germany is co-regulated by international laws and also by the transnational laws of 
the European Union. The incorporation of European law requires regular adjustments at the national level. This was also the case in 2014, since all three directives of the Common European Asylum System (CEAS) were reissued a year before. Thus, in response to the EU's revised Reception Conditions Directive, the German government, led by the Christian-Democratic party in coalition with the Social-Democratic party, began the 18th legislative period by issuing the "Act to Classify Other States and Safe Countries of Origin and on Facilitating Labour Market Access for Asylum Seekers and Foreign Nationals with Exceptional Leave to Remain". ${ }^{3}$ This was followed by eleven more laws influencing the conditions for people applying for a residence permit on humanitarian grounds (see Table 1).

All twelve laws, except the last one, contain at least one measure benefitting asylum seekers in Germany (see Table A1 in the Annex for an overview of the concrete improvements and restrictions regarding the asylum procedure and applicants' reception; see also BAMF, 2015b, 2016d, 2017b; Grote, 2018). I will concentrate the following analysis on those six laws which restructured the humanitarian reception in Germany most profoundly. The first law, which aims to facilitate access to the labour market, reduced the time for which asylum seekers are prohibited from gaining employment to three months, in accordance with the Reception Conditions Directive of the CEAS. However, more consequential for the structure of humanitarian reception was this law's extension of the list of so-called "safe countries of origin" to include Bosnia-Hercegovina, Macedonia and Serbia-already included in the list were all member states of the European Union, Ghana and Senegal; safe countries of origin are countries "in which, on the basis of their laws, enforcement practices and general political conditions, it can be safely concluded that neither political persecution nor inhumane or degrading punishment or treatment exists" (Asyl \& Migration, n.d.).

Nationals of safe countries of origin are to undergo shortened asylum procedures and have fewer opportunities to appeal a negative decision. This measure was created in the context of increasing numbers of migrants from Southeast Europe who claimed asylum after traveling to Germany as tourists, which had become easier after a liberalization of visa regulations in 2009. Thus, the first migration-related legislative initiative of the government after the elections in autumn 2013 was a law which addressed this situation by excluding migrants from Southeast European countries from the standard asylum procedures.

Since "the summer of migration" in 2015, this attempt to reduce humanitarian migration from the Balkans has run parallel to a supportive gesture for those perceived as "genuine" refugees, mostly from war- shaken Syria. The first law from this period is the Asylum Package I, officially referred to as the Act on the Acceleration of Asylum Procedures, issued in October 2015. It took less than a month from the first draft until its release, which is highly remarkable given the fact that all parliamentary decisions concerning migration legislation not only have to pass the parliament (Bundestag) but also the federal assembly (Bundesrat). Table 1 gives evidence that all these laws were issued extremely fast; none took longer than six months, and most were issued in about two to three months' time.

Part of the Asylum Package I was a series of provisions which aimed at the fast incorporation of particular asylum seekers into German society, but not all of them. German courses and certain measures supporting one's integration into the labour market were opened for "foreigners...for whom an enduring and rightful residence is to be expected" (Bundesgesetzblatt, 2015, p. 1728, author's translation). However, the law does not offer any indication of what the grounds for this expectation may be. In practice, the selection is based upon a list published by the Federal Office on Migration and Refugees naming the countries whose nationals are allowed to attend the official German language and society courses (Integrationskurs). Explicitly excluded are asylum seekers from Southeast Europe: "For an asylum seeker who according to $\$ 29$ asylum law comes from a safe country of origin, it is assumed that an enduring and rightful residence is not to be expected" (Bundesgesetzblatt, 2015, p. 1728 , author's translation).

The list of safe countries of origin was also extended as part of Asylum Package I, this time to include Albania, Kosovo and Montenegro. In exchange for these restrictions in the humanitarian sector, some restrictions in $\mathrm{mi}-$ gration legislation concerning access to the labour market were eased for nationals of these countries, changing the migration pattern from Southeast Europe to Germany (Brücker \& Burkert, 2017). Since then work permits can easily be gained at the German diplomatic establishments in one's respective (safe) country of origin, but will not be issued to persons who have received benefits as asylum seekers in Germany within the 24 months prior to their application for a work permit (Burkert \& Haase, 2017). This is how the German migration regime externalized the "selective filtering of mobility" (Mezzadra \& Neilson, 2012, p. 192) and situated it in potential migrants' countries of origin. Mezzandra and Neilson define this externalization as an important technology for differential inclusion (Mezzadra \& Neilson, 2012, p. 192). This externalization is also evident in international trends of humanitarian protection, whereby the processing of claims for humanitarian protection are to take place outside territories like the European Union and near to those conflicts people are fleeing. Those recognized as need-

\footnotetext{
${ }^{3}$ The status referred to as "exceptional leave to remain" /"toleration" (Duldung) was developed as a means of regulating the treatment of people who are not officially entitled to reside in Germany. People usually receive this status after their asylum applications have been denied. "Irrespective of the suspension of deportation, the foreigner's residence in the territory is still illegal and he or she still has the obligation to leave the federal territory" (BAMF, 2016a, p. 22). By the end of June 2017 according the Central Register of Foreigners 159,678 people had this exceptional leave to remain, 32\% of them already living more than 3 years in Germany, 17\% more than 6 years (Deutscher Bundestag, 2017b, p. 38).
} 
Table 1. Overview of laws concerning humanitarian reception which became effective between 2014 and 2017 (18th legislative period of German parliament) in order of entry into force.

\begin{tabular}{|c|c|c|c|c|c|}
\hline & Name of law & 1. draft from: & Issued on: & $\begin{array}{l}\text { Most parts in } \\
\text { force since: }\end{array}$ & $\begin{array}{l}\text { Duration 1st draft } \\
\text { until in force }\end{array}$ \\
\hline 1. & $\begin{array}{l}\text { Act to Classify Other States and Safe } \\
\text { Countries of Origin and on Facilitating } \\
\text { Labour Market Access for Asylum Seekers } \\
\text { and Foreign Nationals with Exceptional } \\
\text { Leave to Remain }\end{array}$ & 26 May 2014 & 31 Oct. 2014 & 06 Nov. 2014 & 24 weeks \\
\hline 2. & $\begin{array}{l}\text { Act to Amend the Asylum Seekers' Benefits } \\
\text { Act and the Social Court Act }\end{array}$ & 12 Aug. 2014 & 10 Dec. 2014 & 19 Dec. 2014 & 19 weeks \\
\hline 3. & $\begin{array}{l}\text { Act to Improve the Legal Status of Asylum } \\
\text { Seekers and Foreign Nationals with } \\
\text { Exceptional Leave to Remain }\end{array}$ & 11 Nov. 2014 & 23 Dec. 2014 & 01 Jan. 2015 & 8 weeks \\
\hline 4. & $\begin{array}{l}\text { Act on the redefinition of the right to stay } \\
\text { and the termination of residence }\end{array}$ & 25 Feb. 2015 & 27 Jul. 2015 & 01 Aug. 2015 & 24 weeks \\
\hline 5. & $\begin{array}{l}\text { Act on the Acceleration of Asylum } \\
\text { Procedures (Asylum Package I) }\end{array}$ & 29 Sep. 2015 & 20 Oct. 2015 & 24 Oct. 2015 & 4 weeks \\
\hline 6. & $\begin{array}{l}\text { Act to improve accommodation, care and } \\
\text { assistance for foreign children and young } \\
\text { persons }\end{array}$ & 07 Sep. 2015 & 28 Oct. 2015 & 01 Nov. 2015 & 8 weeks \\
\hline 7. & Data Sharing Improvement Act & 15 Dec. 2015 & 02 Feb. 2016 & 05 Feb. 2016 & 8 weeks \\
\hline 8. & $\begin{array}{l}\text { Act on the Faster Expulsion of Criminal } \\
\text { Foreigners and Extended Reasons for } \\
\text { Refusing Refugee Recognition to Criminal } \\
\text { Asylum Seekers }\end{array}$ & 16 Feb. 2016 & 11 Mar. 2016 & 17 Mar. 2016 & 5 weeks \\
\hline 9. & $\begin{array}{l}\text { Act on the Introduction of Fast-Track Asylum } \\
\text { Procedures (Asylum Package II) }\end{array}$ & 16 Feb. 2016 & 11 Mar. 2016 & 17 Mar. 2016 & 5 weeks \\
\hline 10. & $\begin{array}{l}\text { Integration Act and its accompanying } \\
\text { Ordinance }\end{array}$ & 31 May 2016 & 31 Jul. 2016 & 06 Aug. 2016 & 10 weeks \\
\hline 11. & Act to Fight Child Marriages & 25 Apr. 2017 & 17 Jul. 2017 & 22 Jul. 2017 & 13 weeks \\
\hline 12. & $\begin{array}{l}\text { Act to Improve the Enforcement of the } \\
\text { Obligation to Leave the Country (Asylum } \\
\text { Package III) }\end{array}$ & 16 Mar. 2017 & 20 Jul. 2017 & 29 Jul. 2017 & 20 weeks \\
\hline
\end{tabular}

Notes: For an overview of all 18 laws concerning migration legislation, including those for EU-citizens and all resident foreigners, see Tometten (2017). For a description of the measures taken and the wider context, see BAMF (2015b, 2016d, 2017b) and Grote (2018).

ing protection are then to be resettled in European countries, Australia, Canada or the United States (Crisp, 2003). But the German case of externalization is slightly different: migration out of impoverished living conditions was rerouted by legislation out of the field of humanitarian reception into that of (unskilled) labour migration.

With the Asylum Package II in 2016, nationals of safe countries of origin were obliged to live in special reception centres for up to 6 months, while the time limit for processing asylum claims was to be shortened to one week and for appeals, to one additional week. Given the fact that asylum seekers do not receive social benefits in special reception centres as cash which would enable them to pay a lawyer and that there is no legal counselling available in the special reception centres (BAMF, 2016c, p. 4; Janke, 2016), appeals are rarely successful. It is intended that rejected applicants "voluntarily" return or are deported directly from the special reception centre in a total of three weeks' time.

In August 2016 the Integration Act was issued, including further measures to ease and open opportunities for integration for a subgroup of refugees, asylum seekers and persons with an exceptional leave to remain. The improvements in the Integration Act opened paths especially for persons with an exceptional leave to remain, whose status could be prolonged if they start an apprenticeship. If they successfully end their vocational training and find $a$ job, there is the possibility that they may gain a residence permit and change their status from a humanitarian to a labour migrant. However, this legislation also 
made it possible to require people to take German language and society courses and accept employment possibilities provided by administrative offices, and to issue a fine of up to 30,000 EUR if incorrect, delayed or incomplete information was given in the course of their asylum procedures.

The last of this series of law issuances was the Asylum Package III, which consisted solely of restrictions and was clearly aimed at ensuring that rejected asylum seekers and criminal offenders are quickly returned to their country of origin. This law was issued in the aftermath of highly publicized attacks on New Year's Eve 2015, when men described as "southern", "Arab" or "North African" were accused of having sexually assaulted and robbed several women around the main station of Cologne (similar incidents were reported in other German cities as well). In this context, the media and societal discourse concerning refugees changed. Concerns were raised that it may not be possible to integrate such a high number of culturally foreign people-meaning Muslims (apa/dpa, 2016). Already the Asylum Package II reflected these changes in discourse. From then on, the practice of more or less balancing the measures supporting and restricting asylum seekers was abandoned (see Figure 1). Even the Integration Act contained more restrictive measures than supportive ones.

Nearly all of the above-mentioned six laws released in the 18th legislation period to define entitlements for individuals applying or who have already applied for humanitarian protection, include measures which structure the everyday life of asylum seekers, whether they were in mid-process, approved or denied. In effect a new order was created, establishing the existence of: 1) "genuine" refugees who were expected to receive a residence permit for fast track integration, 2) "illegitimate" refugees from safe countries of origin, who were systematically excluded from all integration measures and entry into the labour market and separated into special reception centres, and 3) the rest of the applicants. Nevertheless, the most important changes were not introduced by any law, but rather through an administrative measure, a set of procedures called "integrated refugee management", which started in 2016 with the aim of dealing with the high numbers of new asylum applications.

\section{Administrative Innovation through Integrated Refugee Management}

Parallel with the start of the "summer of migration" in 2015, arrival centres were being successfully tested in two places (BAMF, 2017b, p. 42). The result was a process model (Arbeitsstab Integriertes Flüchtlingsmanagement, 2016), accompanied by a bundle of legislative changes regarding the digitization of asylum procedure documentation in a core database associated with the existing Central Registry of Foreigners:

The list of collected data [for the Central Registry of Foreigners] was extended (fingerprints, country of origin, contact data such as address, phone numbers and e-mail addresses, information on allocation [the assigned place of residence] and information on health

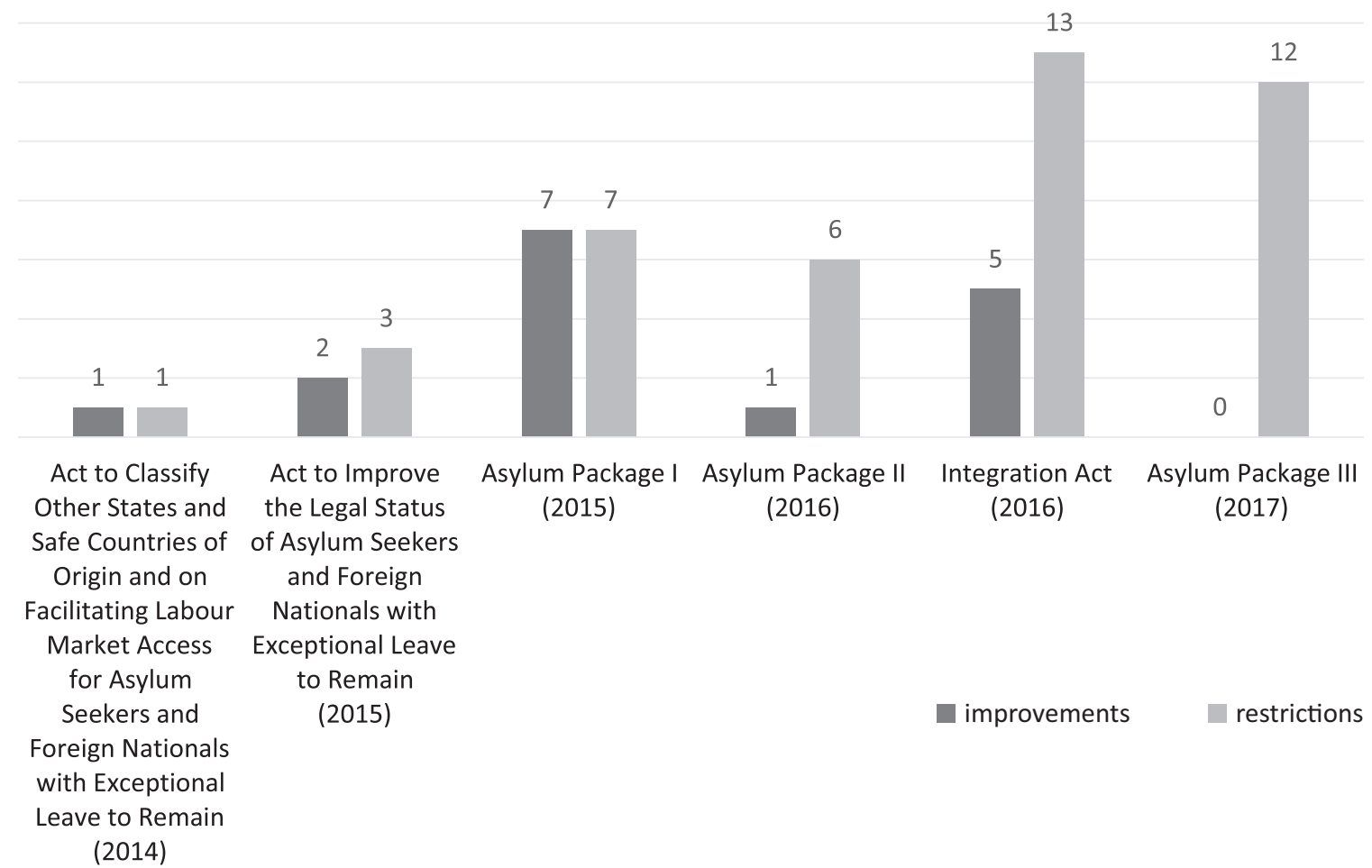

Figure 1. Number of improvements and restrictions from the perspective of individuals applying for a humanitarian status in Germany. Notes: The concrete improvements and restrictions can be found in Table A1 in the Annex. 
examinations and vaccinations). In order to facilitate the foreigners' quick integration and job placement, data on their education, vocational training and other qualifications are to be stored in the Central Register of Foreigners. (BAMF, 2017b, p. 41)

The additional data to be collected are defined by the Data Sharing Improvement Act (Datenaustauschverbesserungsgesetz), and several authorities have access to it (BAMF, 2017b, p. 41). The Integration Act also enables further entities to record information in the core database regarding applicants' attendance at their German language and society course, as well as the results of their examinations at the end of the course. This shows that the administrative changes in humanitarian reception were neatly linked to digitization, which was thought to be the key to speeding up and standardizing procedures. At the same time, the staff of the Federal Office of Migration and Refugees doubled from about 3,300 in 2014 to approximately 7,650 employees in 2016 (BAMF, 2016d, p. 49, 2017b, p. 42).

Also new branch offices of the Federal Office of Migration and Refugees have been opened; since 2016 some offices have been situated directly in the newly established arrival centres. "By end-2016 [sic], the Federal Office for Migration and Refugees had 47 local branch offices and 24 arrival centres....Whenever possible, the entire asylum procedure takes place 'under one roof' in the arrival center" (BAMF, 2017b, p. 42). All federal states have at least one arrival centre, where the "integrated refugee management" (integriertes Flüchtlingsmanagement) was administered (BAMF, 2017b, p. 42). In addition, a short-lived but influential method for categorizing asylum seekers was developed and used in 2016, but discontinued in 2017, because the numbers of new arrivals returned to the level reported in 2014.

According to this categorizing method, newly arrived refugees were sorted into four clusters: $A, B, C$ or $D$ (BAMF, 2017b, p. 42). Cluster $A$ included nationalities with a high protection rate, which had to be above $50 \%$ for the former year. ${ }^{4}$ Persons in cluster A were to get immediate support for their integration, their asylum applications should be processed in 48 hours and a short CV should be entered into the core database, so that the employment office in the future place of residence can prepare measures for integration concerning German language skills, vocational training and employment. Persons in cluster $A$ should be able to leave the arrival centre very quickly.

It is important to note that the clustering method and integrated refugee management more generally are procedures of public administration which lack legislation clearly spelling out the criteria for using them. In practice, the asylum applicants which the integrated refugee management procedures placed in cluster A were from countries on the above-mentioned list issued by the Fed- eral Office of Migration and Refugees since Asylum Package I to specify which asylum applicants were to gain admission to official German language and society courses even before a decision about their asylum application was made. On the list were Syria, Iran, Iraq, Somalia and Eritrea, but not Afghanistan, even if the protection rate in 2016 for Afghan nationals was 55.8\% (BAMF, 2017a, p. 51). Following the definition of cluster A, Afghan nationals should have profited in 2017-when the protection rate of Afghans decreased to about 44\% (BAMF, 2018a; Deutscher Bundestag, 2017a)-from the high protection rate of their co-nationals in the previous year, for example by being able to enter German language and society courses before awaiting a decision on their asylum application. However, this was not the case since this list was not updated.

In cluster B citizens were grouped together whose co-nationals' protection rate was under $20 \%$ in the last year. Also their applications were to be processed in 48 hours, so that they, too, may have a quick decision on whether they should leave Germany or could remain. In 2016, cluster B only included nationals from safe countries of origin (BAMF, 2017b, p. 42). Cluster C consisted of "complex cases", meaning all applicants whose conationals had a protection rate between 20 and $50 \%$. In these cases, the regular decision centres of the Federal Office of Migration and Refugees have to examine the asylum claim without any time limits. This is also supposed to be true for those cases from cluster B which cannot be decided in 48 hours; these should be handed over to the regular decision centres. However, given the fact that cluster B only included citizens from safe countries of origin and no other nationalities with a protection rate lower than $20 \%$, there were practically no cases which were re-categorized from cluster B into cluster $\mathrm{C}$.

Finally, cluster D contained "Dublin-cases", which are persons whose fingerprints were found in EURODAC, the shared European database of fingerprints for asylum seekers in Europe. If a fingerprint is found in the system, that person had already been registered elsewhere in Europe and is not allowed to apply for asylum in Germany. Dublin-cases have to wait until the European country where they were registered accepts their readmission.

These four clusters were an innovation of the administrative procedures called "integrated refugee management" and were never mentioned in any of the various laws passed during this period. It is not clear to which degree the clustering contributed to reducing the average asylum procedure time from 11.3 months in 2014 (BAMF, 2015a, p. 54) to 8.7 months in 2016 (BAMF, 2017a, p. 55). In 2015 the duration was only 7.9 months (BAMF, 2016b, p. 55), but due to the high number of humanitarian migrants it was not possible to apply for asylum immediately after registration. For this reason, there was a gap between the number of registered persons and asylum applications which was not considered in the calculation

\footnotetext{
${ }^{4}$ The protection rate is the number of positive decisions (for asylum according to the German constitution, refugee status, subsidiary protection or (inter-)national bans of deportation) in relation to all decisions on asylum claims for citizens of a certain country.
} 
of the average duration of asylum procedures (BAMF, 2016b, p. 10).

The reduction in average asylum procedure time comparing 2014 with 2016 might instead be the result of the above-mentioned rigorous increase in staff of the Federal Office of Migration and Refugees. However, quick decisions in cluster $A$ and $B$ were only relevant for new arrivals. Since the number of first asylum applications has dropped back to 2014 levels, these clustering methods were abandoned altogether in 2017 (BAMF, $2018 \mathrm{~b})$, and the average duration of asylum procedures has risen again to 10.4 months (Deutscher Bundestag, 2017 a, p. 15). Although it is no longer being used, the central element of the cluster method, i.e., differentiation by citizenship (clusters A, B and C), increased the importance of one's nationality, still influencing the logic of stratification used today.

\section{The Evolvement of New Hierarchies, Differential Access to Resources and Requirements for Integrational Performance}

The several legislative changes between 2014 and 2017 led to a division among asylum seekers into "genuine" refugees from countries whose nationals had a high protection rate and "illegitimate" refugees from safe countries of origin. That was the first step in the development of a citizenship-structured hierarchy of people who claim a status on humanitarian grounds in Germany. The creation and maintenance of nation states is tightly connected to bureaucratic innovations like the passport, which itself shapes modern identity (Noiriel, 1994/2016). Even if the clustering method officially no longer exists, an asylum seeker's passport ${ }^{5}$ still determines whether he/she will be steered toward the fasttrack to integration (with more opportunities) or toward the fast-track to return (with more pressure). Decisive is whether he/she comes from one of the few countries whose nationals have a high possibility of receiving a humanitarian residence permit or if he/she is a national from one of the listed safe countries of origin, respectively. For individuals from all other countries of origin, the asylum procedures last just as long as before, and the access to integration measures is dependent on the outcome of these procedures. This hierarchical logic of how applications are processed therefore still follows the previous cluster-logic of the integrated refugee management, even if the clusters are no longer employed officially. But not only citizenship is decisive. In the beginning I also introduced performance and deviance as important factors in humanitarian reception. When clustering the restrictions and improvements created by the six considered laws, half of them can be categorized as concerning the three factors citizenship, performance and deviance (Table 2).
The second factor in establishing new hierarchies is the distinction among asylum applicants according to their performance in education, vocational training, German language and society courses and tests and in the labour market. Performance-based residence rights are most important for persons with an exceptional leave to remain, mostly rejected asylum seekers. Since 2016 the Integration Act made performance-based rights relevant for approved asylum seekers as well, in connection with the prolongation of waiting-time for a permanent residence permit from three to five years. Now, he/she (and if applicable also the family members) can only receive a permanent residence permit (Niederlassungserlaubnis) within three years of being recognized as a refugee if his/her "integration performance" is extraordinarily high, i.e., he/she masters the German language, finds a job and earns enough money within three years. Thus, integration performance-translated as German language skills and income-influences the length of time before a permanent settlement visa is granted.

But neither integration performance nor the recognition as a refugee or someone entitled to asylum, leads to a permanent residence permit if the applicant 1) has been sentenced to a crime, 2 ) is a member of a terrorist organization, or 3) has not fulfilled his/her obligations to cooperate with state offices. Cooperation includes, for example, carrying valid identity papers, complying with residence and mobility restrictions and quickly supplying immigration authorities with any needed information during the asylum application or appeal process. However, presenting valid ID papers is an obstacle for everyone who has left their country due to discrimination, the very criteria for which a refugee status is granted. Those leaving a country due to persecution or treatment as second-class citizens have good reasons for being afraid of contacting the diplomatic offices of their countries of origin. This is one of the daily paradoxes of refugee lives (strikingly described by the exiled author Brecht, 1961/2000).

The system of sanctions for deviating from these obligations is the third factor structuring humanitarian reception. These obligations are also relevant for persons with an exceptional leave to remain, especially those who have already lived in Germany for a long period of time. Between 2006 and 2017 different legal measures were taken which sought to grant this group performancebased residence rights. Nonetheless, only a few thousand applicants $(3,503)$ received a residence permit due to the various regulations amended to the Residency Act during this time. It is a small number considering that in September 2017, 32,006 people with an exceptional leave to remain had already resided in Germany for 5 years or more (Deutscher Bundestag, 2017b) and could therefore have applied for a residence permit if they had fulfilled the performance criteria and all their

\footnotetext{
${ }^{5}$ Many asylum seekers have no passports or identity certificates when they enter and have problems gaining them from diplomatic establishments of their countries. But German immigration authorities demand valid passports or identity certificates, thus entrapping the concerned between national administrative logics.
} 
Table 2. Legal measures categorized according to the three factors citizenship, performance and deviance.

\begin{tabular}{|c|c|c|c|}
\hline & Citizenship & Performance & Deviance \\
\hline $\begin{array}{l}\text { Act to Classify Other } \\
\text { States and Safe } \\
\text { Countries of Origin } \\
\text { and on Facilitating } \\
\text { Labour Market Access } \\
\text { for Asylum Seekers } \\
\text { and Foreign Nationals } \\
\text { with Exceptional } \\
\text { Leave to Remain }\end{array}$ & $\begin{array}{l}\text { Bosnia-Hercegovina, } \\
\text { Macedonia and Serbia are } \\
\text { declared safe countries } \\
\text { of origin }\end{array}$ & & \\
\hline $\begin{array}{l}\text { Act to Improve the } \\
\text { Legal Status of Asylum } \\
\text { Seekers and Foreign } \\
\text { Nationals with } \\
\text { Exceptional Leave } \\
\text { to Remain }\end{array}$ & & $\begin{array}{l}\text { Residence was restricted } \\
\text { for asylum seekers and } \\
\text { persons with exceptional } \\
\text { leave to remain who } \\
\text { receive social benefits }\end{array}$ & $\begin{array}{l}\text { - Freedom of movement } \\
\text { restrictions for more than } \\
3 \text { months are established } \\
\text { for criminals and persons } \\
\text { who are required to leave } \\
\text { the country }\end{array}$ \\
\hline \multirow[t]{5}{*}{ Asylum Package I } & $\begin{array}{l}\text { - Asylum seekers with a high } \\
\text { probability of being } \\
\text { accepted are entitled to } \\
\text { join a free German } \\
\text { language and society } \\
\text { course while still in the } \\
\text { asylum process if places } \\
\text { are available }\end{array}$ & $\begin{array}{l}\text { Persons with exceptional } \\
\text { leave to remain have access } \\
\text { to grants for studies after } \\
15 \text { months of lawful stay in } \\
\text { Germany according to the } \\
\text { Federal Training Assistance } \\
\text { Act (BAföG) }\end{array}$ & $\begin{array}{l}\text { - Benefits are cut if a person } \\
\text { does not leave Germany } \\
\text { despite a concrete date for } \\
\text { exit, if he/she does not } \\
\text { obtain the required ID } \\
\text { documents or if the person } \\
\text { is to be sent to a hot spot } \\
\text { in another EU-country }\end{array}$ \\
\hline & $\begin{array}{l}\text { - Asylum seekers with a high } \\
\text { probability of being } \\
\text { accepted have access to } \\
\text { measures supporting their } \\
\text { entrance into the labour } \\
\text { market according to the } \\
\text { Third Book of the } \\
\text { Social Code }\end{array}$ & & \\
\hline & $\begin{array}{l}\text { - Unrestricted employment } \\
\text { for nationals of Albania, } \\
\text { Bosnia-Hercegovina, } \\
\text { Kosovo, Macedonia, } \\
\text { Montenegro and Serbia if } \\
\text { the employment visa is } \\
\text { applied for in the country } \\
\text { of origin and if no reasons } \\
\text { for exclusion exist (e.g., } \\
\text { having received benefits as } \\
\text { part of the Asylum Seekers' } \\
\text { Benefits Act } 24 \text { months } \\
\text { prior to application) }\end{array}$ & & \\
\hline & $\begin{array}{l}\text { Albania, Kosovo and } \\
\text { Montenegro are declared } \\
\text { safe countries of origin }\end{array}$ & & \\
\hline & $\begin{array}{l}\text { - Nationals of safe countries } \\
\text { of origin are prohibited } \\
\text { from employment and may } \\
\text { be allocated to arrival } \\
\text { centres for more than } \\
6 \text { months }\end{array}$ & & \\
\hline
\end{tabular}


Table 2. (Cont.) Legal measures categorized according to the three factors citizenship, performance and deviance.

\begin{tabular}{|c|c|c|c|}
\hline & Citizenship & Performance & Deviance \\
\hline Asylum Package II & $\begin{array}{l}\text { - Fast-track asylum } \\
\text { procedures in one week's } \\
\text { time in special reception } \\
\text { centres, out of which a } \\
\text { deportation is to take place } \\
\text { in three weeks' time } \\
\text { (employed for nationals of } \\
\text { Western Balkan countries) }\end{array}$ & & $\begin{array}{l}\text { - Closure of asylum } \\
\text { procedures if the } \\
\text { concerned do not continue } \\
\text { to pursue their case for } \\
\text { example if they leave the } \\
\text { special reception centres } \\
\text { before they are permitted } \\
\text { to do so }\end{array}$ \\
\hline $\begin{array}{l}\text { Integration Act and its } \\
\text { accompanying } \\
\text { Ordinance }\end{array}$ & $\begin{array}{l}\text { - Asylum seekers with a } \\
\text { good prospect of being } \\
\text { accepted have access to } \\
\text { measures of vocational } \\
\text { training and education } \\
\text { after } 15 \text { months of } \\
\text { residence if the measure } \\
\text { starts before } 31.12 .2018 \\
\text { - Nationals of safe countries } \\
\text { of origin are excluded from } \\
\text { measures of vocational } \\
\text { training and education and } \\
\text { 'Refugee Integration } \\
\text { Measures' (employment } \\
\text { opportunities) }\end{array}$ & 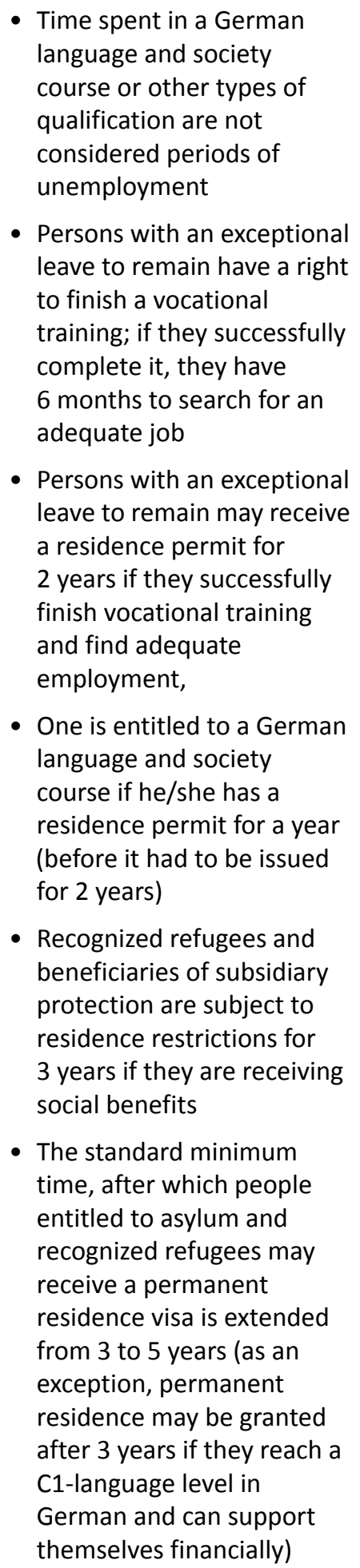 & $\begin{array}{l}\text { - One is obliged to accept } \\
\text { the 'Refugee Integration } \\
\text { Measures' to which one is } \\
\text { assigned } \\
\text { - German language and } \\
\text { society courses may be } \\
\text { made obligatory } \\
\text { - Asylum seekers' benefits } \\
\text { are cut to below the } \\
\text { general calculated } \\
\text { minimum standard of } \\
\text { living if they fail to } \\
\text { cooperate during the } \\
\text { asylum procedures, if they } \\
\text { are absent from asylum } \\
\text { hearings or work } \\
\text { opportunities without an } \\
\text { excuse or if another } \\
\text { EU-country is responsible } \\
\text { for processing the } \\
\text { asylum claim } \\
\text { - Fines may be issued for up } \\
\text { to } 30,000 \text { EUR for wrong, } \\
\text { incomplete or delayed } \\
\text { information during one's } \\
\text { asylum procedures }\end{array}$ \\
\hline
\end{tabular}


Table 2. (Cont.) Legal measures categorized according to the three factors citizenship, performance and deviance.

\begin{tabular}{|c|c|c|}
\hline & Performance & Deviance \\
\hline Asylum Package III & & $\begin{array}{l}\text { - People awaiting their } \\
\text { deportation may be } \\
\text { monitored if they are } \\
\text { considered a threat to } \\
\text { others or internal security } \\
\text { - Persons awaiting } \\
\text { deportation who are } \\
\text { considered a threat to } \\
\text { others or internal security } \\
\text { may be ordered to wear } \\
\text { electronic tagging devices } \\
\text { - One's fatherhood may be } \\
\text { tested if it is suspected } \\
\text { that the recognition of } \\
\text { fatherhood is being abused } \\
\text { - One's freedom of } \\
\text { movement may be } \\
\text { restricted to the district of } \\
\text { the foreigners' authority } \\
\text { where one is registered if } \\
\text { he/she is required to leave } \\
\text { Germany, has provided } \\
\text { false information about } \\
\text { his/her identity or has } \\
\text { failed to cooperate with } \\
\text { arrangements for his/her } \\
\text { deportation } \\
\text { - People required to leave } \\
\text { Germany may be detained } \\
\text { up to } 15 \text { months } \\
\text { residence title may be } \\
\text { investigated due to } \\
\text { is in force } \\
\text { suspicions of a crime or } \\
\text { decision to prolong his/her } \\
\text { itory afgement }\end{array}$ \\
\hline
\end{tabular}

obligations to cooperate with state officials. However, these numbers indicate that a large share of them could not profit from these regulations; most of them probably did not cooperate (enough) with the administration in the course of their asylum application process or during the preparation of their deportation. Furthermore, this number will probably rise in future after the asylum applications from 2015 and 2016 are entirely processed, since Germany will not be able to deport the high number of rejected applicants very quickly. In addition, there is no way for offenders of these regulations to work toward a legal residence permit, even a performance-based one.
In consequence, a new and complex hierarchy of different entitlements to resources and residence permits is evolving. The newly-formed legislation is the basis for the

highly technocratic but also quite arbitrary means of instituting differential inclusion, multiplying and increasingly stratifying the legal statuses of subjects inhabiting the same political space, while at the same time allowing an effective policing of the borders and boundaries between these different subject positions. (Mezzadra \& Neilson, 2012, p. 193) 
People claiming humanitarian protection see themselves confronted with performance expectations even if they had been excluded from integration measures in the beginning which could have helped improve this performance (Schiefer, 2017, p. 60f.). "When political belonging becomes entangled with market calculations the boundaries between state and market are blurred" (Mezzadra \& Neilson, 2012, p. 195f). This blurring of boundaries between state and market is just one collateral effect of the lane change in humanitarian reception. Furthermore, it is difficult for applicants to understand how and why resources are available to some of the compatriots they encountered in refugee accommodations or in German language and society courses and not available to others. Neither is it evident to them why some who perform well in the labour market get a residence permit and others don't. On the individual level, the major impact of differential inclusion is the uncertainty it produces (Schiefer, 2017, pp. 7, 23, 61, 97, 2018; Will, 2009, p. 56ff.).

Differential inclusion is Janus-faced: there are dead ends or even traps for those who cannot perform as needed or who are excluded from the performancebased granting of rights, such as nationals from safe countries of origin. At the same time, opportunities do exist for those who conform to the performance "dispositif" (Foucault, 1978). In the latter case, performing one's integration well is framed as something that improves $\mathrm{him} /$ her and opens up his/her opportunities, while wellintegrated refugees are also portrayed as a potential advantage for Germany, itself, where the general population is decreasing. Henceforth, humanitarian reception is split into several groups, and support for asylum seekers is a challenge because of the increasing complexity and fluidity which makes it very difficult to compare one case with another.

In addition, criticizing the current migration regime is a tricky task, since it also offers new opportunities to applicants for humanitarian status by smoothly following a neoliberal logic of a national welfare state. Even rejected asylum seekers can make it if they complete their vocational education and find an adequate job. But they have to follow the rules of cooperation in the asylum process and comply with preparations for deportation. Hardly anyone who applies for asylum or international protection can and wants to fulfil all of these requirements; therefore, a large number of rejected asylum seekers cannot take advantage of the positive opportunities. They are kept in a precarious waiting position, between a constant threat of deportation and occasional incentives for a voluntary return.

\section{Conclusion}

During the 18th legislative period from 2014 to 2017 a series of laws profoundly restructured the field of humanitarian reception, establishing a nuanced system of differential inclusion which has generated new hierar- chies. The three main organizational axes structuring this hierarchy are citizenship, neo-liberal performance (in the labour market, educational sector and German language und society courses/tests) and strict abidance to laws and obligations. Citizens from safe countries of origin (since 2014-2015 including the Southeast European states Albania, Bosnia-Hercegovina, Kosovo, Macedonia, Montenegro and Serbia) are almost completely excluded from access to humanitarian residence permits. Nationals of countries with high protection rates, such as Eritrea, Iran, Iraq, Somalia and Syria, are entitled to take part in German language and society courses and gain further support for their quick integration even before their cases have been formally decided. All remaining nationals have to wait for a decision in order to gain access to integration measures; however, they, too, can look for a job after three months as long as they are not registered already in another European State, which would then be responsible for their asylum claim. Thus, "illegitimate" refugees from the Balkans and "genuine" refugees from the countries with high protection rates are the two prominent figures rising from recent humanitarian reception policy in Germany. The majority of the diverse and complex migration for humanitarian reasons is not adequately represented.

Central to the innovations in this field, alongside the doubling of staff in the responsible Federal Office for Migration and Refugees, are new data-gathering and dataprocessing possibilities, including the core database as part of the Central Register of Foreigners, as well as the integrated refugee management procedures which employed a clustering method based on citizenship to speed up the processing of new asylum applications. These measures may have successfully reduced application processing times during the phase when the number of new asylum applications was high, but with the reduction in asylum applications, the clustering method has become unnecessary and been discontinued. The arrival centres have thus shifted their focus to processing old asylum applications. Nevertheless, the new logics introduced by the twelve laws and by administrative innovations concerning humanitarian reception have lasting effects.

One of these effects is that the division between market and state has become less distinct. Humanitarian reception has become more complex, which is a challenge for supporters of asylum seekers and the applicants, themselves. Additionally, asylum seekers are split by the new legislation into several status groups with different support entitlements. Last but not least, it is difficult for supporters of humanitarian reception to effectively criticize these measures, since the changes are in line in part with old demands of refugee-supporting activists as well as with neoliberal arguments for the performance-based granting of residence rights. Asylum seekers are thus deemed to be the masters of their own fate, which is not true given the structurally exclusionist restrictions most of them meet. 


\section{Acknowledgments}

I thank my copyreader Melisa Salazar for her support. I also owe a debt of gratitude to the three anonymous reviewers for their constructive feedback and ideas for sharpening my argument. Last but not least, I am thankful to Mr. Wotherspoon and the team of Social Inclusion who thoughtfully supported the development of this publication.

\section{Conflict of Interests}

The author declares no conflict of interests.

\section{References}

apa/dpa. (2016). De Mazière nennt Kölner Silvesternacht "Wendepunkt". Spiegel Online. Retrieved from www.spiegel.de/panorama/gesellschaft/thomas-demaiziere-nennt-koelner-silvesternacht-wendepunkta-1118162-druck.html

Arbeitsstab Integriertes Flüchtlingsmanagement. (2016). Leitfaden zum Aufbau eines Ankunftszentrums. Nürnberg: Bundesamt für Migration und Flüchtlinge. Retrieved from www.nds-fluerat.org/wp-content/ uploads/2017/05/BAMF-Leitfaden-zum-Aufbau-eines -Ankunftszentrums.pdf

Asyl \& Migration. (n.d.). Safe country of origin. Asylum in Europe. Retrieved from www.asylumineurope.org/ reports/country/germany/asylum-procedure/safecountry-concepts/safe-country-origin

BAMF. (2015a). Das Bundesamt in Zahlen 2014. Nürnberg: Bundesamt für Migration und Flüchtlinge. Retrieved from www.bamf.de/SharedDocs/Anlagen/ DE/Publikationen/Broschueren/bundesamt-in-zahlen -2014.pdf?_blob=publicationFile

BAMF. (2015b). Migration, integration, asylum: Political developments in Germany 2014 (Annual Policy Report). Nürnberg: German National Contact Point for the European Migration Network. Retrieved from www.bamf.de/SharedDocs/Anlagen/EN/Publikatio nen/EMN/Politikberichte/emn-politikbericht-2014germany.pdf?_blob=publicationFile

BAMF. (2016a). Approaches to rejected asylum seekers in Germany (Working Paper 69). Nürnberg: German National Contact Point for the European Migration Network. Retrieved from www.bamf.de/SharedDocs/ Anlagen/EN/Publikationen/EMN/Studien/wp69-emn -umgang-abgelehnten-asylbewerbern.pdf?__blob= publicationFile

BAMF. (2016b). Das Bundesamt in Zahlen 2015. Nürnberg: Bundesamt für Migration und Flüchtlinge. Retrieved from www.bamf.de/SharedDocs/Anlagen/ DE/Publikationen/Broschueren/bundesamt-in-zahlen -2015.pdf?_blob=publicationFile

BAMF. (2016c). FAQ-Bundesamt für Migration und Flüchtlinge. Nürnberg: Bundesamt für Migration und Flüchtlinge. Retrieved from asyl-bc.de/application/
files/1414/6554/5237/BAMF_Infos_20160509_FAQ_ Presse.pdf

BAMF. (2016d). Migration, integration, asylum: Political development in Germany 2015 (Annual Policy Report). Nürnberg: German National Contact Point for the European Migration Network. Retrieved from www.bamf.de/SharedDocs/Anlagen/EN/Publikatio nen/EMN/Politikberichte/emn-politikbericht-2015germany.pdf?_blob=publicationFile

BAMF. (2017a). Das Bundesamt in Zahlen 2016. Nürnberg: Bundesamt für Migration und Flüchtlinge. Retrieved from www.bamf.de/SharedDocs/Anlagen/ DE/Publikationen/Broschueren/bundesamt-in-zahlen -2016.pdf?_blob=publicationFile

BAMF. (2017b). Migration, integration, asylum: Political developments in Germany 2016 (Annual Policy Report). Nürnberg: German National Contact Point for the European Migration Network. Retrieved from www.bamf.de/SharedDocs/Anlagen/EN/Publikatio nen/EMN/Politikberichte/emn-politikbericht-2016germany. pdf;jsessionid=4C6AA7AB720BC3A5D7C1A 4C8BF448FF9.1_cid359?_blob=publicationFile

BAMF. (2018a). Asylgeschäftsstatistik. Nürnberg: Bundesamt für Migration und Flüchtlinge. Retrieved from www.bamf.de/SharedDocs/Anlagen/DE/Downloads/ Infothek/Statistik/Asyl/hkl-antrags-entscheidungsbestandsstatistikl-kumuliert-2017.pdf?__blob=pub licationFile

BAMF. (2018b). Meldung zum Clusterverfahren. Bundesamt für Migration und Flüchtlinge. Retrieved from www.bamf.de/SharedDocs/Anlagen/DE/Publikatio nen/Broschueren/das-deutsche-asylverfahren.html? $\mathrm{nn}=7919970$

Bojadzijev, M., Mezzadra, S., Altenried, M., Höfler, L., \& Wallis, M. (2016). Migration und Logistik: Politiken und Vermittlung mobiler Arbeit. In Solidarität im Wandel? (pp. 260-283). Berlin: Berliner Instituts für empirische Integrations und Migrationsforschung. Retrieved from www.integrationsbeauftragte.de/ Webs/IB/DE/Service/Downloads/forschung-bim-soli daritaet.pdf?_blob=publicationFile\&v=1

Brecht, B. (2000). Flüchtlingsgespräche. Frankfurt: Suhrkamp. (Original work published 1961)

Brücker, H., \& Burkert, C. (2017). Westbalkanregelung: Arbeit statt Asyl? IAB Forum. Retrieved from www. iab-forum.de/westbalkanregelung-arbeit-statt-asyl

Bundesgesetzblatt. (2015). Asylverfahrensbeschleunigungsgesetz. Bundesgesetzblatt. Retrieved from www.bgbl.de/xaver/bgbl/start.xav?startbk=Bundes anzeiger_BGBI\&start=//*\%255B@attr_id='bgbl115s 1722.pdf'\%255D\#_bgbl_\%2F\%2F*\%5B\%40attr_id \%3D\%27bgbl115s $\overline{17} 22 . p d f \% 27 \% 5 D \_15312354123$ 99

Burkert, C., \& Haase, M. (2017). Westbalkanregelung: Ein neues Modell für die Migrationssteuerung? WISO Direkt, 2(2017). Retrieved from library.fes.de/pdffiles/wiso/13156.pdf

Crisp, J. (2003). Refugees and the global politics of asy- 
lum. The Political Quarterly, 74(1), 75-87.

Deutscher Bundestag. (2017a). Ergänzende Informationen zur Asylstatistik für das erste Quartal 2017 (Drucksache 18/12623). Berlin. Retrieved from dip21.bundestag.de/dip21/btd/18/126/1812623.pdf

Deutscher Bundestag. (2017b). Zahlen in der Bundesrepublik Deutschland lebender Flüchtlinge zum Stand 30. Juni 2017 (Drucksache 18/13537). Berlin. Retrieved fromdip21.bundestag.de/dip21/btd/18/ 135/1813537.pdf

Foucault, M. (1978). Dispositive der Macht: Über Sexualität, Wissen und Wahrheit. Berlin: Merve Verl.

Grote, J. (2018). The changing influx of Asylum seekers in 2014-2016: Responses in Germany (Working Paper 79). Nürnberg: German National Contact Point for the European Migration Network. Retrieved from www.bamf.de/SharedDocs/Anlagen/EN/Publikatio nen/EMN/Studien/wp79-emn-fluchtmigration-2014 -2016-reaktionen-maßnahmen-deutschland.pdf? blob=publicationFile

Grote, J., \& Vollmer, M. (2016). Opportunities to change the residence title and the purpose of stay in Germany (Working Paper 67). Nürnberg: German National Contact Point for the European Migration Network. Retrieved from www.bamf.de/SharedDocs/ Anlagen/EN/Publikationen/EMN/Studien/wp67-emn -wechsel-aufenthaltstiteln-aufenthaltszwecken.pdf? blob=publicationFile

Janke, C. (2016). Neue "Aufnahmeeinrichtungen" für schnellere Abschiebungen. Mediendienst-Integration. Retrieved from mediendienst-integration.de/ artikel/asylpaket-asylverfahren-beschleunigte-verfah ren-besondere-aufnahmeeinrichtung-transitzonefluechtlin.html

Mezzadra, S., \& Neilson, B. (2012). Borderscapes of differential inclusion: Subjectivity and struggles on the threshold of justice's excess. In: Balibar, É., Mezzadra, S., \& Sammadar, R. (Eds.), The borders of justice (181-203). Philadelphia, PA: Temple University Press.

Morris-Lange, S., \& Brands, F. (2015). Zugangstor Hochschule. Internationale Studierende als Fachkräfte von morgen gewinnen. Berlin: Sachverständigenrat deutscher Stiftungen für Integration und Migration. Retrieved from www.svr-migration. de/wp-content/uploads/2015/06/SVR-FB_Zugangs tor_Hochschule.pdf

Noiriel, G. (2016). Die Tyrannei des Nationalen: Sozialgeschichte des Asylrechts in Europa (2. Auflage). Heidelberg: Springer. (Original work published 1994)

Parusel, B. (2009). The granting of non-EU harmonised protection statuses in Germany (Working Paper 30). Nürnberg: Bundesamt für Migration und Flüchtlinge. Retrieved from www.bamf.de/SharedDocs/Anlagen/ EN/Publikationen/EMN/Studien/wp30-emn-schutzge waehrung.pdf?_blob=publicationFile

Schiefer, D. (2017). Wie gelingt Integration? Asylsuchende über ihre Lebenslagen und Teilhabeperspektiven in Deutschland. Berlin: Sachverständigenrat deutscher Stiftungen für Integration und Migration. Retrieved from www.svr-migration.de/ wp-content/uploads/2017/11/SVR-FB_Wie_gelingt_ Integration.pdf

Schiefer, D. (2018). Viele Fragen, zu viele Antworten? Die Transparenz des Asyl- und Aufnahmesystems für Flüchtlinge. Retrieved from www.svr-migration.de /wp-content/uploads/2018/06/SVR-FB_Systemtrans parenz.pdf

Sykes, B., Ni Chaoimh, E. (2012). Mobile Talente? Ein Vergleich der Bleibeabsichten internationaler Studierender in fünf Staaten der Europäischen Union. Berlin: Sachverständigenrat deutscher Stiftungen für Integration und Migration. Retrieved from www. svr-migration.de/wp-content/uploads/2012/04/Studie _SVR-FB_Mobile_Talente.pdf

Tometten, C. (2017). Migrationsrecht im Parlament im Rahmen der Vorlesung "Einführung in das europäische Asylsystem". Retrieved from docplayer. org/72091917-Migrationsrecht-im-parlament.html

Will, A.-K. (2009). Verhandeln + Behandeln = Psychologisierung menschlicher Leidenserfahrungen. Therapieerfahrungen bosnischer Flüchtlinge in Berlin (Unpublished Doctorial dissertation). Institut für Europäische Ethnologie an der Humboldt-Universität zu Berlin. Retrieved from edoc.hu-berlin.de/ bitstream/handle/18452/16716/will.pdf?sequence= 1\&isAllowed=y

\section{About the Author}

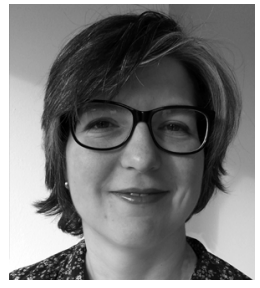

Anne-Kathrin Will (PhD) is a Social Anthropologist at the German Centre for Integration and Migration Research working interdisciplinary on various themes of migration and societal participation of migrants and their descendants. She headed the project team for the founding of the German Centre for Integration and Migration Research at Humboldt-University of Berlin. Her research focus are processes of boundary making in the invention and maintenance of natio-ethnic and medico-psychological categorizations, humanitarian and family legislations and the intersections in these fields. 
Annex

Table A1. Improvements and restrictions in six laws issued from 2014 until 2017 in the field of humanitarian reception.

\begin{tabular}{|c|c|}
\hline & Improvements \\
\hline $\begin{array}{l}\text { Act to Classify Other States } \\
\text { and Safe Countries of Origin } \\
\text { and on Facilitating Labour } \\
\text { Market Access for Asylum } \\
\text { Seekers and Foreign Nationals } \\
\text { with Exceptional Leave to } \\
\text { Remain } \\
\end{array}$ & $\begin{array}{l}\text { 1. Reduced time period in which labour } \\
\text { market access is prohibited for asylum } \\
\text { seekers and foreigners with } \\
\text { exceptional leave to remain to } 3 \\
\text { months (from } 9 \text { or } 12 \text { months) }\end{array}$ \\
\hline \multirow[t]{2}{*}{$\begin{array}{l}\text { Act to Improve the Legal } \\
\text { Status of Asylum Seekers and } \\
\text { Foreign Nationals with } \\
\text { Exceptional Leave to Remain }\end{array}$} & $\begin{array}{l}\text { 1. Reduced duration of freedom of } \\
\text { movement restrictions (only } \\
\text { movement within the district of the } \\
\text { foreigners' office where one is } \\
\text { registered) to a maximum of } 3 \text { months }\end{array}$ \\
\hline & $\begin{array}{l}\text { 2. Encouraged granting benefits in cash, } \\
\text { as long as the concerned live in } \\
\text { accommodations outside of reception } \\
\text { centres }\end{array}$ \\
\hline
\end{tabular}

Restrictions

1. Bosnia-Hercegovina, Macedonia and Serbia are declared safe countries of origin

1. Residence was restricted for asylum seekers and persons with exceptional leave to remain who receive social benefits

2. Freedom of movement restrictions for more than 3 months are established for criminals and persons who are required to leave the country

3. Inhabitants of reception centres are to receive non-cash benefits as vouchers or as measures in kind if the investment is deemed justifiable

1. Albania, Kosovo and Montenegro are declared safe countries of origin

2. Asylum seekers can be forced to reside for up to 6 months in arrival centres with freedom of movement restrictions and prohibition of employment

3. Nationals of safe countries of origin are prohibited from employment and may be allocated to arrival centres for more than 6 months

3. Unrestricted employment for nationals of Albania, Bosnia-Hercegovina, Kosovo, Macedonia, Montenegro and Serbia if the employment visa is applied for in the country of origin and if no reasons for exclusion exist (e.g., having received benefits as part of the Asylum Seekers' Benefits Act 24 months prior to application)

4. Persons with exceptional leave to remain have access to grants for studies after 15 months of lawful stay in Germany according to the Federal Training Assistance Act (BAföG)

5. Opening a bank account is to be made easier (the foreigners' authorities' replacement documents for ID-papers are to be accepted by banks)

6. 16 and 17 years olds are considered minors in procedures according to the Asylum Act
4. Benefits are cut if a person does not leave Germany despite a concrete date for exit, if he/she does not obtain the required ID documents or if the person is to be sent to a hot spot in another EU-country

5. People will no longer be informed about their deportations in advance

6. Unaccompanied minors may be redistributed throughout the Federal Republic

7. Duration of exceptional leave to remain according to $\S 60$ a sentence 1 (Residence Act) is reduced to 3 months (from 6 months) 
Table A1. (Cont.) Improvements and restrictions in six laws issued from 2014 until 2017 in the field of humanitarian reception.

\begin{tabular}{lll}
\hline & Improvements & Restrictions \\
\hline Asylum Package I & $\begin{array}{l}\text { 7. } \\
\text { Receiving a health insurance card is } \\
\text { to be possible if the administrative } \\
\text { district works in cooperation with } \\
\text { health insurance companies }\end{array}$ \\
\hline
\end{tabular}

Asylum Package II

1. Responsible bodies for reception centres have to ensure that employees and volunteers who have contact with minors provide an extended certificate of good conduct submitted to authorities (according to $\S 30$ (5) und $\S 30 a$ (1) BZRG)

1. Family reunification is suspended for beneficiaries of subsidiary protection

2. Fast-track asylum procedures in one week's time in special reception centres, out of which a deportation is to take place in three weeks' time (employed for nationals of Western Balkan countries)

3. Closure of asylum procedures if the concerned do not continue to pursue their case for example if they leave the special reception centres before they are permitted to do so

4. Suspending deportations for health reasons is restricted to cases where a life-threatening or serious illness would worsen if the deportation were carried out

5. Reasons for not deporting someone have to be provided by the person concerned; the foreigners' office does not have to investigate this on its own

6. Cash benefits are reduced according to the Asylum Seekers' Benefits Act by an average of 8 EUR

1. Time spent in a German language and society course or other types of qualification are not considered periods of unemployment

2. Asylum seekers with a good prospect of being accepted have access to measures of vocational training and education after 15 months of residence if the measure starts before 31.12.2018

3. Persons with an exceptional leave to remain have a right to finish a vocational training; if they successfully complete it, they have 6 months to search for an adequate job
1. Nationals of safe countries of origin are excluded from measures of vocational training and education and 'Refugee Integration Measures' (employment opportunities)

2. 'Refugee Integration Measures' (employment opportunities) are reimbursed with 0,80 Euro per hour (i.e., 20\% less than so-called '1-Euro-Jobs', those work opportunities in Germany which are reimbursed with at least one Euro per hour)

3. One is obliged to accept the 'Refugee Integration Measures' to which one is assigned 
Table A1. (Cont.) Improvements and restrictions in six laws issued from 2014 until 2017 in the field of humanitarian reception.

\begin{tabular}{|c|c|}
\hline & Improvements \\
\hline \multirow[t]{2}{*}{ Integration Act } & $\begin{array}{l}\text { 4. Persons with an exceptional leave } \\
\text { to remain may receive a residence } \\
\text { permit for } 2 \text { years if they } \\
\text { successfully finish vocational } \\
\text { training and find adequate } \\
\text { employment, }\end{array}$ \\
\hline & $\begin{array}{l}\text { 5. One is entitled to a German } \\
\text { language and society course if } \\
\text { he/she has a residence permit for a } \\
\text { year (before it had to be issued for } \\
2 \text { years) }\end{array}$ \\
\hline
\end{tabular}

\section{Restrictions}

4. Recognized refugees and beneficiaries of subsidiary protection are subject to residence restrictions for 3 years if they are receiving social benefits

5. Asylum seekers' benefits are cut to below the general calculated minimum standard of living if they fail to cooperate during the asylum procedures, if they are absent from asylum hearings or work opportunities without an excuse or if another EU-country is responsible for processing the asylum claim

6. Asylum seekers' data is to be collected and exchanged between governmental authorities and institutions providing education (such as German language and society courses) or work opportunities

7. German language and society courses may be made obligatory

8. When benefits are cut and the concerned sue to get the benefits back, they no longer automatically receive benefits again until the court decides; the benefits now remain cut until the court decides that they should be paid out again

9. The standard minimum time, after which people entitled to asylum and recognized refugees may receive a permanent residence visa is extended from 3 to 5 years (as an exception, permanent residence may be granted after 3 years if they reach a C1-language level in German and can support themselves financially)

10. Asylum seekers' private sponsors are liable for 5 years for any costs incurred, even if the respective persons are granted residence on humanitarian grounds

11. Fines may be issued for up to 30,000 EUR for wrong, incomplete or delayed information during one's asylum procedures 
Table A1. (Cont.) Improvements and restrictions in six laws issued from 2014 until 2017 in the field of humanitarian reception.

Improvements Restrictions

Integration Act

12. The authorities which execute one's asylum hearings may be changed, i.e., not only the Federal Office of Migration and Refugees may execute them, but also the border police and others

13. Asylum claims cannot be admitted for people who received a refugee status in a third country or lived there safely for at least for 3 months

1. People awaiting their deportation may be monitored if they are considered a threat to others or internal security

2. Persons awaiting deportation who are considered a threat to others or internal security may be ordered to wear electronic tagging devices

3. One's fatherhood may be tested if it is suspected that the recognition of fatherhood is being abused

4. One's freedom of movement may be restricted to the district of the foreigners' authority where one is registered if he/she is required to leave Germany, has provided false information about his/her identity or has failed to cooperate with arrangements for his/her deportation

5. People required to leave Germany may be detained up to 15 months

6. If someone is being investigated due to suspicions of a crime or regulatory offence, a decision to prolong his/her residence title may be withheld until a judgement is in force

7. The travels of persons entitled to asylum and recognized refugees to their home countries are to be reported to asylum authorities to reconsider the grounds on which asylum was granted

8. Personal data may be transferred to other authorities 
Table A1. (Cont.) Improvements and restrictions in six laws issued from 2014 until 2017 in the field of humanitarian reception.

\section{Improvements}

Asylum package III

\section{Restrictions}

9. Asylum seekers are obliged to show or hand over data storage devices as well as mobile telephones if no valid identification documents are available for verification of identity

10. Data collected by the Federal Criminal Police Office may be transferred to third countries (i.e., not country of origin) to verify the identity of an asylum seeker, as long as the protection rights of the asylum seeker are respected

11. Federal states may require asylum seekers to reside in a reception centre until an asylum decision is made, and require rejected asylum seekers to reside there until their return to their home country, but 24 months at most

12. Minors in need of humanitarian protection may no longer first be assigned a custodian and wait until later to go through the difficult application process; the youth welfare office is now obliged to immediately submit an asylum application for them

Note: Legal measures which are neither restrictive nor improving the situation of those under the legislation are not listed, as for example renaming the Asylum Procedure Act (AsylVfG) as Asylum Act (AsylG). 